\title{
Ball-flower-like carbon microspheres via a three- dimensional replication strategy as a high-capacity cathode in lithium-oxygen batteries
}

\author{
Liang Xiao ${ }^{1^{*}}$, Jingyu $\mathrm{Yi}^{1}$, Wen Meng ${ }^{1}$, Shiyao Wang ${ }^{1}$, Bohua Deng ${ }^{1}$ and Jinping $\mathrm{Liu}^{1,2^{*}}$
}

\begin{abstract}
The robust porous architectures of active materials are highly desired for oxygen electrodes in lithiumoxygen batteries to enable high capacities and excellent reversibility. Herein, we report a novel three-dimensional replication strategy to fabricate three-dimensional architecture of porous carbon for oxygen electrodes in lithium-oxygen batteries. As a demonstration, ball-flower-like carbon microspheres assembled with tortuous hollow carbon nanosheets are successfully prepared by completely replicating the morphology of the nanostructured zinc oxide template and utilizing the polydopamine coating layer as the carbon source. When used as the active material for oxygen electrodes, the three-dimensional porous architecture of the prepared ballflower-like carbon microspheres can accommodate the discharge product lithium peroxide and simultaneously maintain the ions and gas diffusion paths. Moreover, their high degrees of defectiveness by nitrogen doping provide sufficient active sites for oxygen reduction/evolution reaction. Thus the prepared ball-flower-like carbon microspheres demonstrate a high capacity of $9,163.7 \mathrm{~mA} \mathrm{~h}^{-1}$ and excellent reversibility. This work presents an effective way to prepare three-dimensional architectures of porous carbon by replicating the controllable nanostructures of transition metal oxide templates for energy storage and conversion applications.
\end{abstract}

Keywords: three-dimensional replication, porous carbon, oxygen electrodes, lithium-oxygen batteries, zinc oxide nanostructure

\section{INTRODUCTION}

In the last decade, lithium-oxygen $\left(\mathrm{Li}-\mathrm{O}_{2}\right)$ batteries have attracted intensive studies because of their ultra-high theoretical energy density of $3,505 \mathrm{~W} \mathrm{~h} \mathrm{~kg}^{-1}$ based on the discharge product of $\mathrm{Li}_{2} \mathrm{O}_{2}$ in the cathode [1]. $\mathrm{Li}-\mathrm{O}_{2}$ batteries are even considered as promising energy storage candidates for meeting the demands of future electric vehicles (EVs). However, so far, several critical obstacles including low energy efficiency, low rate capability, and poor cycle life still hinder the practical applications of $\mathrm{Li}-\mathrm{O}_{2}$ batteries $[2,3]$. These obstacles are mainly ascribed to the sluggish kinetics of oxygen reduction reaction (ORR) and oxygen evolution reaction (OER) in the oxygen electrodes with aprotic electrolytes [4]. Moreover, the insoluble and insulating discharge product $\mathrm{Li}_{2} \mathrm{O}_{2}$ is another key issue for oxygen electrodes. The $\mathrm{Li}_{2} \mathrm{O}_{2}$ deposited inside the oxygen electrode during discharge not only blocks the diffusion pathways of electrolyte and oxygen but also deteriorates the electron transfer of the electrochemical reactions [5-7]. To tackle these challenges in the previous reports, porous structures of electrode materials and oxygen electrodes have been rationally designed to maintain the mass diffusion and electron transfer paths in the cathodic side [8-15].

Among the potential materials for oxygen electrodes, porous/nanoporous carbon materials are intensively studied because of their high conductivities, low costs and abundant resources $[11,16,17]$. It has been demonstrated that the performances of oxygen electrodes strongly depend on the porosities of carbon materials. The carbon materials with higher mesopore volumes would accommodate more $\mathrm{Li}_{2} \mathrm{O}_{2}$ and maintain the diffusion paths for electrolyte and oxygen during charge and discharge, and consequently enable higher capacity and lower polarization [12,18-20]. Generally, the utilization ratio of carbon materials would be low in a laminated electrode especially with high loading mass

\footnotetext{
${ }^{1}$ School of Chemistry, Chemical Engineering and Life Sciences, Wuhan University of Technology, Wuhan 430070, China

${ }^{2}$ State Key Laboratory of Advanced Technology for Materials Synthesis and Processing, Wuhan University of Technology, Wuhan 430070, China

* Corresponding authors (emails: xiaoliang@whut.edu.cn (Xiao L); liujp@whut.edu.cn (Liu J))
} 
since the aggregation of carbon powders would lose some active surfaces and the binders would block some pores. To enhance the utilization ratio of porous carbon, threedimensional (3D) porous architectures of nanostructured carbon materials have been proposed for preparing a more efficient oxygen electrode [11]. Xiao et al. [21] demonstrated that a novel air electrode consisting of an unusual hierarchical arrangement of functionalized graphene sheets delivers an exceptionally high capacity of $15,000 \mathrm{~mA} \mathrm{~h} \mathrm{~g}^{-1}$ in Li-air batteries. Zhang et al. [22] reported the preparation of free-standing, hierarchically porous carbon derived from graphene oxide gel in nickel foam. When employed as a cathode for $\mathrm{Li}-\mathrm{O}_{2}$ batteries, the discharge specific capacity of the free-standing carbon electrode reaches $11,060 \mathrm{~mA} \mathrm{~h} \mathrm{~g}^{-1}$. Recently, Lin et al. [23] reported the ultrahigh capacity $\left(40 \mathrm{~mA} \mathrm{~h} \mathrm{~cm}^{-2}\right)$ of air cathode enabled by dry-pressed holey graphene. In summary, the 3D porous architectures of carbon materials are highly desired to ensure the effectiveness of the battery reactions in $\mathrm{Li}-\mathrm{O}_{2}$ batteries that are already sluggish intrinsically.

Although porous carbon has been widely utilized as the cathode material for $\mathrm{Li}-\mathrm{O}_{2}$ batteries, its reactivity with superoxide radicals and its catalysis effect on electrolyte decomposition have difficulties on the stability and cycle life of porous carbon cathodes [24-26]. When charging the carbonaceous cathode to above $3.5 \mathrm{~V} v s . \mathrm{Li}^{+} / \mathrm{Li}$, carbon materials are oxidized to form $\mathrm{Li}_{2} \mathrm{CO}_{3}$, which accumulates during repeated cycling and then deteriorates the electrode performance very quickly [25]. In this situation, OER catalysts are mandatorily required to suppress the charge overpotential and consequently achieve a longer cycle life. For instance, Wang et al. [27] successfully synthesized mesoporous carbon nanocubes by a cubic $\mathrm{MnCO}_{3}$ hard template through a chemical vapor deposition (CVD) process. After functionalized with $\mathrm{Ru}$ nanocrystals, the Ru-loaded carbon nanocube composite catalysts exhibit a significantly reduced charge overpotential, high round-trip energy efficiency, and excellent cycling stability. Yin et al. [11] prepared a hierarchical macroporous active carbon fiber (MACF) electrode by electrostatic spinning the silica spheres embedded polyacrylonitrile, which is inspired by the golden-toad spawning process as well as the favorable shape and structure of the eggs. The ruthenium oxide nanoparticle-decorated binder-free MACF electrodes exhibit excellent electrochemical performances including a high full-cycle energy efficiency, good cycle stability, and especially superior rate capability. Therefore, the rationally designed three-dimensional porous architec- tures of carbon materials suitable for catalyst loading are important for further improving the performances of $3 \mathrm{D}$ porous oxygen electrodes.

To this end, herein, we propose a novel threedimensional (3D) replication strategy to fabricate carbon microspheres with ball-flower-like 3D porous architectures for oxygen electrodes in $\mathrm{Li}-\mathrm{O}_{2}$ batteries. As presented in Scheme 1, the ball-flower-like $\mathrm{ZnO}$ microspheres assembled by tortuous nanosheets are prepared and used as the templates. The dopamine monomer (commercially available as dopamine hydrochloride) can be oxidized and spontaneously self-polymerize under alkaline conditions ( $\mathrm{pH}>7.5)$ with oxygen in the air as the oxidant. Therefore, the surfaces of $\mathrm{ZnO}$ nanostructures are fully and evenly covered by a polydopamine thin film under Tris-buffer with $\mathrm{pH}$ 8.5. Virtually, polydopamine can be easily deposited on all types of inorganic and organic substrates, including superhydrophobic surfaces, with controllable film thickness and durable stability [28]. Then, at $850^{\circ} \mathrm{C}$ and $\mathrm{N}_{2}$ atmosphere, the polydopamine coating film decomposes to nitrogen-doped carbon material. At the elevated temperature, $\mathrm{ZnO}$ will be reduced during the carbonization process through the reaction $\mathrm{ZnO}+\mathrm{C} \rightarrow \mathrm{Zn}+\mathrm{CO}$, and subsequently $\mathrm{Zn}$ metal (boiling point $908^{\circ} \mathrm{C}$ ) will vaporize away along with the gas flow leaving carbon species alone. In this reaction, the derived carbon coating layer will be consumed in some extent and the residual carbon layer will replicate the morphology of $\mathrm{ZnO}$ template. Eventually, ball-flower-like carbon microspheres assembled with tortuous hollow carbon nanosheets are prepared by completely replicating the morphology of nanostructured $\mathrm{ZnO}$ template. When used as the materials for oxygen electrodes in the present study, high capacity and excellent reversibility (can be fully charged) of the prepared ball-flower-like carbon microspheres are demonstrated.

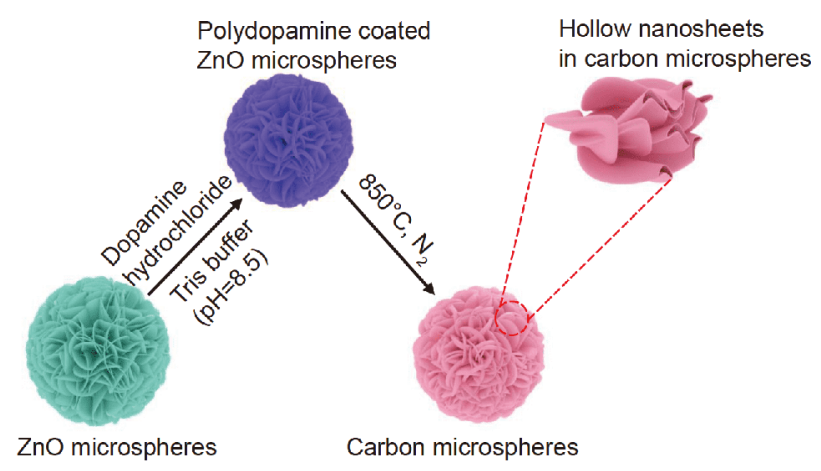

Scheme 1 Illustration of the three-dimensional replication strategy. 


\section{EXPERIMENTAL SECTION}

\section{Materials and preparation}

The nanostructured $\mathrm{ZnO}$ microspheres used as the templates were prepared by a hydrothermal route according to our previous report [29]. Firstly, the aqueous solutions of $0.01 \mathrm{~mol} \mathrm{~L}^{-1}$ zinc nitrate hexahydrate $\left(\mathrm{Zn}\left(\mathrm{NO}_{3}\right)_{2} \cdot 6 \mathrm{H}_{2} \mathrm{O}\right), 0.01 \mathrm{~mol} \mathrm{~L}^{-1}$ hexamethylenetetramine (HMT, $\mathrm{C}_{6} \mathrm{H}_{12} \mathrm{~N}_{4}$ ), and $0.1 \mathrm{~mol} \mathrm{~L}^{-1}$ trisodium citrate $\left(\mathrm{Na}_{3} \mathrm{C}_{6} \mathrm{H}_{5} \mathrm{O}_{7} \cdot 2 \mathrm{H}_{2} \mathrm{O}\right)$ were prepared respectively. Then, $30 \mathrm{~mL}$ of the zinc nitrate solution, $30 \mathrm{~mL}$ of the HMT solution and $2 \mathrm{~mL}$ of the trisodium citrate solution were mixed and stirred thoroughly. The mixed solution was transferred to a Teflon-lined autoclave with the capacity of $100 \mathrm{~mL}$ for hydrothermal synthesis at $95^{\circ} \mathrm{C}$ in an oven for $12 \mathrm{~h}$, after which the autoclave was removed from the oven and allowed to cool to room temperature. The resulting white precipitate in the autoclave was collected and washed with deionized water several times before being dried in a vacuum oven at $130^{\circ} \mathrm{C}$ for $12 \mathrm{~h}$.

For a typical synthesis of three-dimensional architectures of porous carbon, $100 \mathrm{mg}$ of the as-prepared $\mathrm{ZnO}$ microspheres was mixed with various amounts of dopamine hydrochloride $(50,80$, and $100 \mathrm{mg}$ ) in a Tris buffer $\left(75 \mathrm{~mL}, 10 \mathrm{mmol} \mathrm{L}^{-1} ; \mathrm{pH} 8.5\right)$ and then stirred for $24 \mathrm{~h}$ open to the air. The polydopamine coated samples were collected by centrifugation and washed three times using water. To carbonize the polydopamine coating and simultaneously remove the $\mathrm{ZnO}$ template, the dried powders were placed in a tube furnace and heated under $\mathrm{N}_{2}$ at $850^{\circ} \mathrm{C}$ for $3 \mathrm{~h}$ with a heating rate of $2^{\circ} \mathrm{C} \mathrm{min}^{-1}$. The resultant products were denoted as $\mathrm{CF}-\mathrm{X}$, where $\mathrm{X}$ represents the mass of dopamine hydrochloride in $\mathrm{mg}$ used in the preparation. Commercially available Super P (SP) carbon was used as the reference in this work.

\section{Characterizations}

The morphologies of the pristine $\mathrm{ZnO}$ microspheres, the prepared $\mathrm{CF}-\mathrm{Xs}$, and the discharged cathodes were examined with a Zeiss Ultra-Plus field emission scanning electron microscope (FE-SEM). Transmission electron microscopy (TEM) images were taken with a JEM 2100F electron microscope operating at $200 \mathrm{kV}$. The nitrogen adsorption-desorption data were measured with a Quantachrome Autosorb-1 analyzer at $-196^{\circ} \mathrm{C}$. Prior to the measurement, the samples were first degassed at $200^{\circ} \mathrm{C}$ for at least $6 \mathrm{~h}$. The surface areas were calculated by the Brunauer-Emmett-Teller (BET) method. The pore size distributions were derived from the adsorption branches of the isotherms using the Barrett-Joyner-
Halenda (BJH) model. The thermogravimetric and differential thermal analysis (TG-DTA) were carried out on a SDT Q600 thermal analyzer. Raman spectra of $\mathrm{CF}-\mathrm{Xs}$ and discharged electrodes were obtained on a Raman spectrophotometer (Renishaw inVia). The X-ray photoelectron spectra (XPS) were recorded on a VG Multilab2000X X-ray photoelectron spectrometer with an $\mathrm{Al} \mathrm{Ka}$ excitation source, where binding energies were calibrated by referencing the $\mathrm{C} 1 \mathrm{~s}$ peak $(284.6 \mathrm{eV})$ to reduce the sample charge effect. For the inductively coupled plasma-atomic emission spectrometry (ICP-AES) analysis, CF-Xs were thoroughly stirred in $2.0 \mathrm{~mol} \mathrm{~L}^{-1}$ $\mathrm{HCl}$ solution overnight; after filtration, the filter liquor was collected for the test of residual $\mathrm{Zn}$ element on a Perkin Elmer Optima 4300DV spectrometer.

The oxygen cathodes were prepared by casting the slurry of $\mathrm{CF}-\mathrm{Xs}$ and polyvinylidenedifluoride ( $\mathrm{pVDF}$ ) binder in a mass ratio of 9:1 on a carbon paper used as the gas diffusion layer. The $\mathrm{CF}-\mathrm{Xs}$ loading densities were around $1 \mathrm{mg} \mathrm{cm}^{-2}$. The SP electrode was prepared by the same route as the reference. After punching into circular pieces with a diameter of $9 / 16$ inch, the electrodes were dried further in a $120^{\circ} \mathrm{C}$ vacuum oven overnight. In an Argon-filled glovebox with $\mathrm{O}_{2}$ and $\mathrm{H}_{2} \mathrm{O}$ levels less than $0.1 \mathrm{ppm}$, the $\mathrm{Li}-\mathrm{O}_{2}$ battery was assembled into a R2032 coin cell with a glass fiber separator (GF/D, Whatman), a lithium foil (with the diameter of $1.56 \mathrm{~cm}$ and the thickness of $1.5 \mathrm{~mm}$ ) as the anode, and a piece of prepared oxygen cathode. Holes (diameter of $1 \mathrm{~mm}, 21$ holes) were punched in the bottom canister of the coin cells for oxygen flow. $1 \mathrm{~mol} \mathrm{~L}^{-1}$ lithium bis(trifluoromethane)sulfonamide (LiTFSI) in tetraethylene glycol dimethyl ether (TEGDME) was used as the electrolyte. The prepared cells were put into an oxygen container with the pressure of $1 \mathrm{~atm}$. Galvanostatic discharge/ charge and cycling tests for as-prepared $\mathrm{Li}-\mathrm{O}_{2}$ batteries were conducted on a Land CT3008W battery testing system at room temperature. The discharged and charged cathodes were disassembled from the coin cells and then washed with TEGDME several times for SEM and Raman spectrum analysis. Prior to the analysis, they were dried and kept in the glove box.

\section{RESULTS AND DISCUSSION}

The morphologies of the prepared $\mathrm{ZnO}$ template and the derived CF-Xs were investigated by SEM and TEM. As shown in Fig. 1a, the prepared $\mathrm{ZnO}$ microsphere exhibits a 3D ball-flower-like morphology assembled by tortuous nanosheets. In the hydrothermal preparation, HMT hydrolyzes in water to produce ammonia, and therefore 

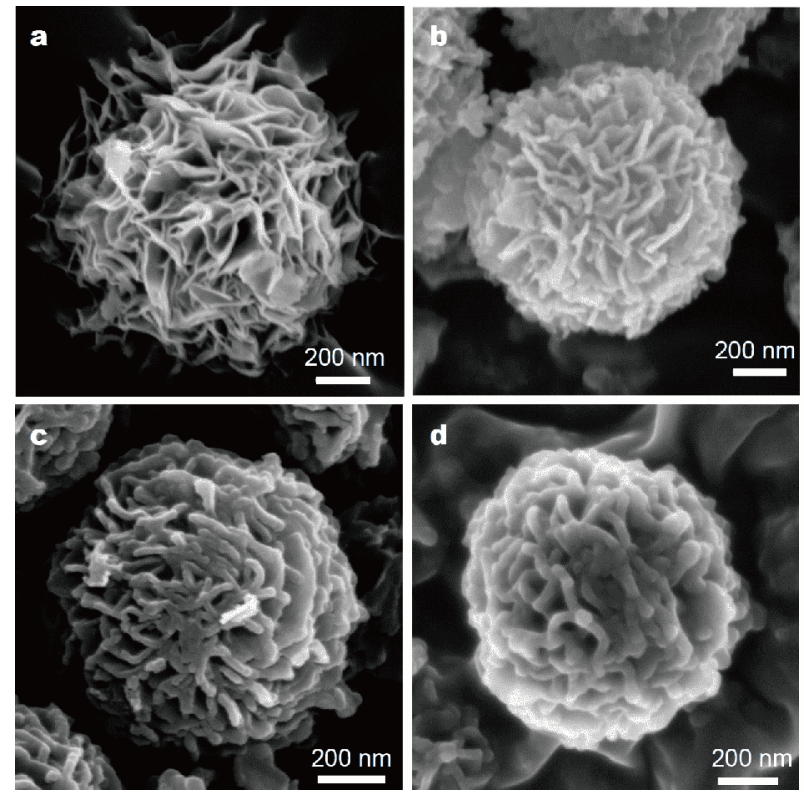

Figure $1 \mathrm{SEM}$ images of (a) $\mathrm{ZnO}$ microspheres template and ballflower-like carbon microspheres: (b) CF-50, (c) CF-80, and (d) CF-100.

acts as a $\mathrm{pH}$ buffer to provide a slow and controlled supply of $\mathrm{OH}^{-}$anions. Trisodium citrate preferentially adsorbs to certain surfaces of the $\mathrm{ZnO}$ nucleation seeds and alters the crystal growth process leading to a rapid and extensive growth of flexible nanosheets [29,30]. When used as a template, the morphologies of $\mathrm{ZnO}$ microspheres are completely replicated by the derived carbon microspheres shown in Fig. 1b-d. All the CF-50, CF-80 and CF-100 show a similar ball-flower-like morphology except the different thicknesses of the "flower petals" (i.e. the tortuous carbon nanosheets of the derived carbon microspheres). The low-magnification SEM images of $\mathrm{ZnO}$ microspheres and $\mathrm{CF}-\mathrm{Xs}$ are shown in Fig. S1 (Supporting Information). The diameters of $\mathrm{ZnO}$ microspheres and $\mathrm{CF}-\mathrm{Xs}$ are uniform, which range from 1 to $2 \mu \mathrm{m}$. As discussed in Scheme 1 for the reaction mechanism, the derived carbon coating layer will be consumed in some extent. If the dopamine is less than $20 \mathrm{mg}$ per $100 \mathrm{mg} \mathrm{ZnO}$, after the reduction reaction of $\mathrm{ZnO}$ and $\mathrm{C}$, the residual carbon layer will be too little to maintain the ball-flower-like nanostructures. The nanostructure of $\mathrm{ZnO}$ microspheres will collapse to nanoparticles aggregation as shown in Fig. S2. By contrast, when the quality of dopamine is higher than $50 \mathrm{mg}$ per $100 \mathrm{mg}$ $\mathrm{ZnO}$, the residual carbon layer will remain to replicate the morphology of $\mathrm{ZnO}$ template (see Fig. 1).

The ball-flower-like morphologies of $\mathrm{CF}-\mathrm{Xs}$ and the hollow structure of the tortuous carbon nanosheets as the
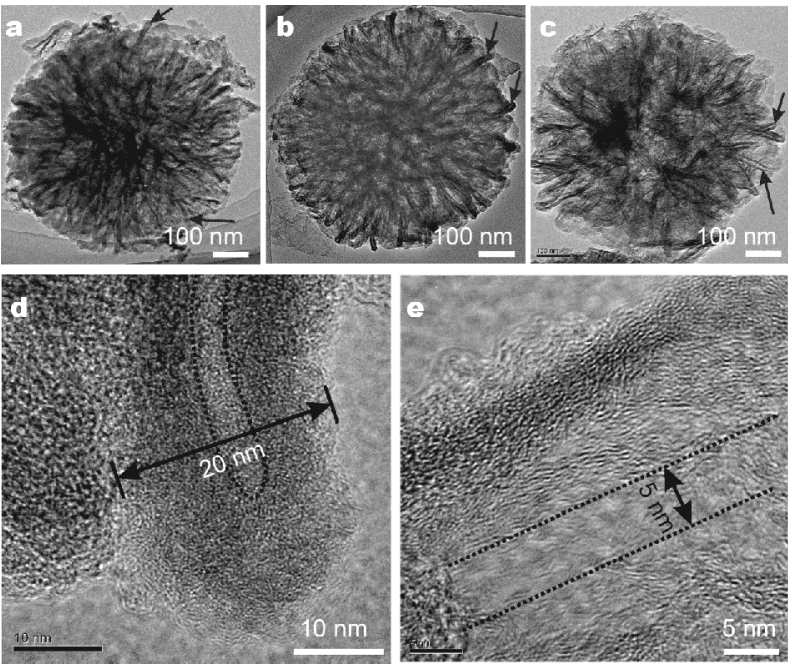

Figure 2 TEM images of (a) CF-50, (b) CF-80, and (c) CF-100, HRTEM images of $(\mathrm{d}, \mathrm{e}) \mathrm{CF}-100$.

building blocks are further confirmed by TEM analysis. Fig. 2a-c show the TEM images of $\mathrm{CF}-50, \mathrm{CF}-80$, and $\mathrm{CF}$ -100 , respectively. All the CF-Xs replicate the morphologies of $\mathrm{ZnO}$ microspheres template, showing a microsphere composed of tortuous hollow nanosheets. Taking CF-100 as an example, the thicknesses of the hollow layers marked with dash line in Fig. 2d, e are around $5 \mathrm{~nm}$, and the total thicknesses of the carbon nanosheets including the hollow layers are around $20 \mathrm{~nm}$. In lower magnification, the hollow layers of $\mathrm{CF}-100$ are clearly observed in Fig. $2 c$ which are marked with arrows. By the comparison of Fig. $2 \mathrm{a}-\mathrm{c}$, it is found that the thicknesses of the hollow layers and the carbon nanosheets (marked with arrows) slightly shrink with the decrease of the thicknesses of polydopamine coating layers, resulting in the gradually shrinking morphologies from $\mathrm{CF}-100, \mathrm{CF}$ -80 to $\mathrm{CF}-50$. These results indicate that appropriate coating is required to maintain the morphology of template and mitigate the shrink, and too little coating would lead to the collapse of nanostructures (Fig. S2).

The pore structures of $\mathrm{CF}-\mathrm{Xs}$ and SP are studied by nitrogen adsorption-desorption tests. Fig. 3 shows the nitrogen sorption isotherms and the inserted $\mathrm{BJH}$ pore size distributions of the SP and $\mathrm{CF}-\mathrm{Xs}$. The corresponding structural properties including BET specific surface areas and total pore volumes are summarized in Table 1. In Fig. 3a, SP shows a type III isotherm arising from nonporous surface [31]. Therefore, the pore distribution curve of SP comes from the interparticle pores. In contrast, all three $\mathrm{CF}-\mathrm{Xs}$ samples exhibit representative type IV isotherms (Fig. 3b-d), which are the character- 

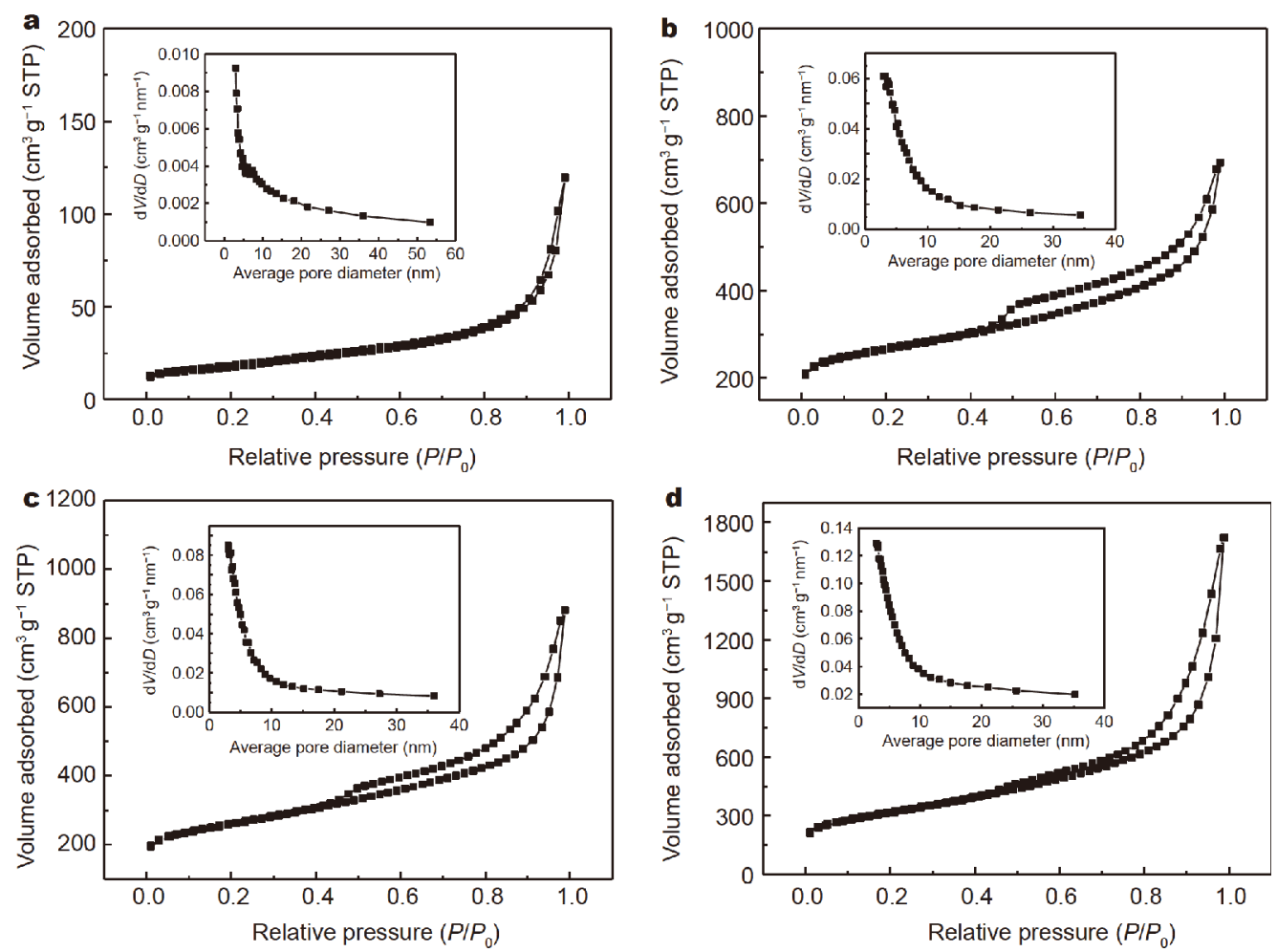

Figure $3 \mathrm{~N}_{2}$ sorption isotherms and inserted BJH pore size distributions of (a) SP and the prepared ball-flower-like carbon materials: (b) CF-100, (c) CF-80, (d) CF-50.

Table 1 The structural properties of SP and $\mathrm{CF}-\mathrm{Xs}$

\begin{tabular}{ccccc}
\hline Samples & SP & CF-100 & CF-80 & CF-50 \\
\hline$S_{\text {BET }}\left(\mathrm{m}^{2} \mathrm{~g}^{-1}\right)$ & 60.0 & 729.3 & 772.1 & 1007.8 \\
$V_{\text {total }}\left(\mathrm{cm}^{3} \mathrm{~g}^{-1}\right)$ & 0.124 & 0.907 & 1.36 & 2.66 \\
\hline
\end{tabular}

istics of mesoporous materials. The $\mathrm{H}_{3}$-type hysteresis loops are observed for $\mathrm{CF}-\mathrm{Xs}$, implying that there are many interstices between parallel plates. These results confirm the observation in the TEM study that $\mathrm{CF}-\mathrm{Xs}$ have the microsphere morphology composed of tortuous hollow nanosheets. Although the thickness of the hollow layers is uniform as observed from the TEM images, no obvious peak is observed in the distribution curves. This is because that the pore distribution curves of $\mathrm{CF}-\mathrm{Xs}$ include the pores inside and between the nanosheets in the microspheres and even the interparticle pores which have a wide distribution. The structural properties summarized in Table 1 indicate that, with the decrease of polydopamine coating thickness in the precursors, the BET surface area $\left(S_{\mathrm{BET}}\right)$ and the total pore volume $\left(V_{\text {total }}\right)$ of the derived carbon materials increase in the order of $\mathrm{CF}-100, \mathrm{CF}-80$, and $\mathrm{CF}-50$. Among the three samples, $\mathrm{CF}-50$ shows the highest surface area of $1,007.9 \mathrm{~m}^{2} \mathrm{~g}^{-1}$ and the highest pore volume of $2.66 \mathrm{~cm}^{3} \mathrm{~g}^{-1}$. This result is in good agreement with the TEM results in Fig. 2a-c, since it is reasonable that $\mathrm{CF}-\mathrm{Xs}$ with thinner carbon nanosheets and thinner hollow layers exhibit higher surface areas and pore volumes.

The chemical components of $\mathrm{CF}-\mathrm{Xs}$ were studied by TG-DTA, Raman spectrum and XPS spectrum in Fig. 4. The results of $\mathrm{CF}-100$ are discussed as an example since the chemical components of $\mathrm{CF}-\mathrm{Xs}$ are very similar. As shown in Fig. 4a, the TG curve of $\mathrm{CF}-100$ exhibits two distinct weight loss steps and the DTA curve shows one endothermic peak and one exothermic peak. The first $10 \%$ weight loss less than $100^{\circ} \mathrm{C}$ accompanied by a small endothermic peak centered at around $50^{\circ} \mathrm{C}$ could be attributed to the loss of adsorbed water and gas. The second weight loss step in the temperature range of 400 to $600^{\circ} \mathrm{C}$ corresponds to the combustion of the carbon material, which is accompanied by one exothermic peak around $560^{\circ} \mathrm{C}$. Above $600^{\circ} \mathrm{C}$, there are only $7 \mathrm{wt} \%$ remains, indicating that the main component of $\mathrm{CF}-\mathrm{Xs}$ is carbon and there are residual $\mathrm{ZnO}$ encapsulated by carbon materials. In addition, the $\mathrm{ZnO}$ content in $\mathrm{CF}$ -100 determined by ICP-AES is $6.5 \mathrm{wt} \%$, which is very close to the TG analysis. In Fig. $4 \mathrm{~b}$, two peaks are 

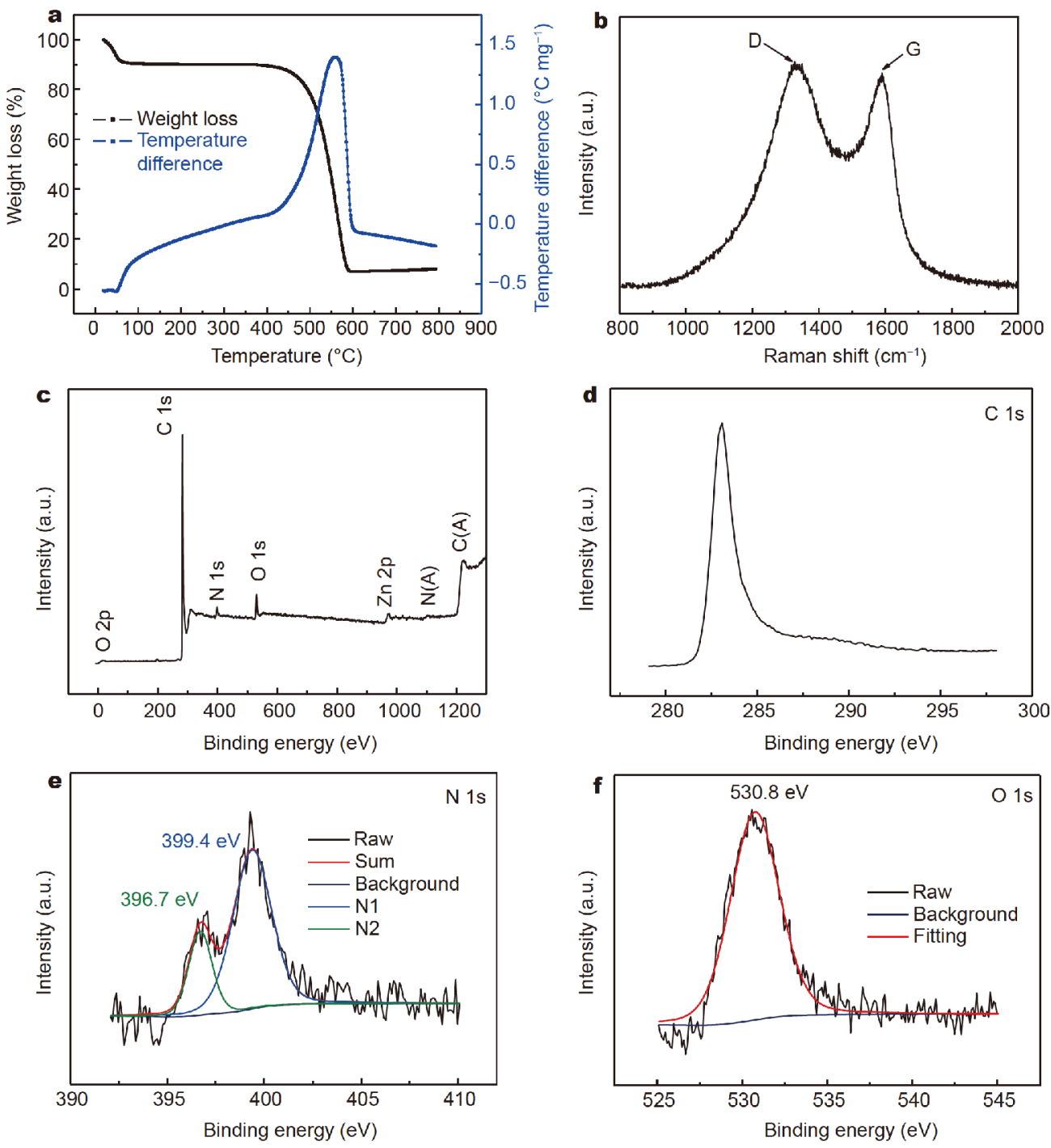

Figure 4 (a) The thermogravimetric and differential thermal curves and (b) the Raman spectrum of CF-100; the XPS spectra of CF-100: (c) survey spectrum, (d) N 1s, (e) C 1s, and (f) O 1s.

observed from the Raman spectrum of $\mathrm{CF}-100$. The band at around $1,335 \mathrm{~cm}^{-1}$ (D-band) is originated from atomic displacements and disorders induced by lattice defects and distortions, while the band at around $1,590 \mathrm{~cm}^{-1}(\mathrm{G}$ -band) indicates the formation of well graphitized carbon nanosheets. The $I_{\mathrm{D}} / I_{\mathrm{G}}$ ratio of $\mathrm{CF}-100$ is 2.84 . The very high $I_{\mathrm{D}} / I_{\mathrm{G}}$ ratios of CF-Xs imply the high defectiveness of the graphite like layers and the nitrogen doping.

Fig. $4 \mathrm{c}-\mathrm{f}$ shows the XPS spectra of $\mathrm{CF}-100$. The survey spectrum in Fig. $4 \mathrm{c}$ shows the presence of $\mathrm{C}$ and trace amount of $\mathrm{Zn}, \mathrm{O}$, and $\mathrm{N}$. The high resolution XPS spectrum for the $\mathrm{C} 1 \mathrm{~s}$ region is shown in Fig. $4 \mathrm{~d}$. The $\mathrm{C} 1 \mathrm{~s}$ peak at $284.6 \mathrm{eV}$ was attributed to the hydrocarbon adsorbed on all specimens, which is usually used as binding energy reference. The high-resolution $\mathrm{N} 1 \mathrm{~s}$ spectrum given in Fig. 4e reveals the presence of both pyridinic $(396.7 \mathrm{eV}$, peak N2) and pyrrolic $(399.4 \mathrm{eV}$, peak N1) nitrogen atoms within the graphite structure. From the peak intensity analysis, the content of $\mathrm{N}$ doped in $\mathrm{CF}-100$ is calculated to be 4.01 at $\%$. The binding energy component at $530.8 \mathrm{eV}$ in Fig. $4 \mathrm{f}$ was attributed to the hexagonal close packing $\mathrm{O}^{2-}$ in the wurtzite $\mathrm{ZnO}$ structure, confirming that there are residual $\mathrm{ZnO}$ encapsulated by carbon materials. All the abovementioned results demonstrate that all the prepared $\mathrm{CF}-\mathrm{Xs}$ ball-flower-like microspheres are composed of tortuous hollow carbon nanosheets with nitrogen atom doping and defects. 

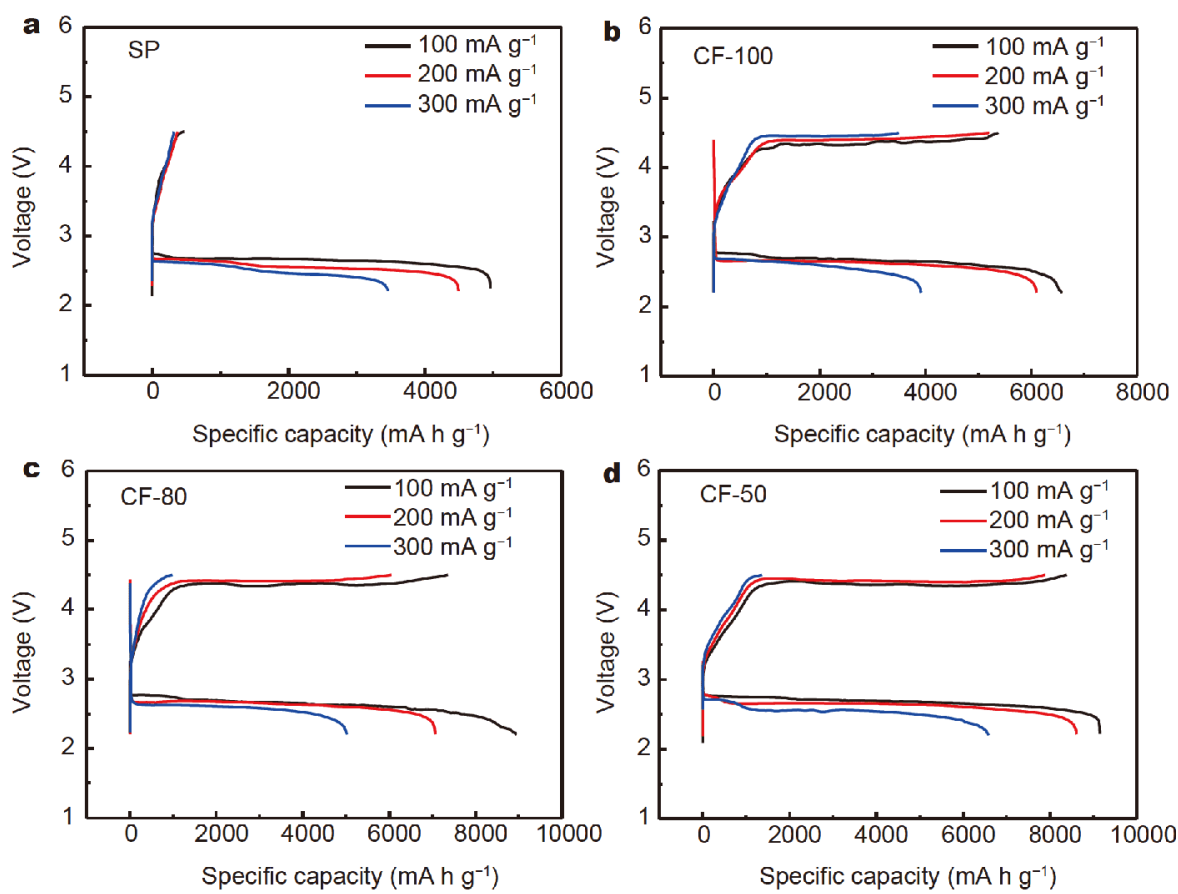

Figure 5 Voltage profiles of (a) SP, (b) $\mathrm{CF}-100$, (c) $\mathrm{CF}-80$, and (d) $\mathrm{CF}-50$ at 100,200 , and $300 \mathrm{~mA} \mathrm{~g}^{-1}$ in the first cycle from 2.2 to $4.5 \mathrm{~V}$.

Fig. 5 shows the discharge and charge curves of $\mathrm{Li}-\mathrm{O}_{2}$ cells utilizing an oxygen electrode prepared with SP or CF -Xs in the first cycle from 2.2 to $4.5 \mathrm{~V}$ at different current densities. The specific capacities are calculated based on the mass of carbon materials. As a reference in this study, SP electrode exhibits a specific capacity of $4,963.4 \mathrm{~mA} \mathrm{~h} \mathrm{~g}^{-1}$ at the current density of $100 \mathrm{~mA} \mathrm{~g}^{-1}$. By contrast, at the same current density of $100 \mathrm{~mA} \mathrm{~g}^{-1}$, CF-100, $\mathrm{CF}-80$, and $\mathrm{CF}-50$ shows the specific capacities of $6,523.0,8,948.6$, and $9,163.7 \mathrm{~mA} \mathrm{~h} \mathrm{~g}^{-1}$, respectively. These results coupled with the structural properties of SP and $\mathrm{CF}-\mathrm{Xs}$ summarized in Table 1 demonstrate that the $\mathrm{CF}-\mathrm{Xs}$ with higher surface areas and pore volumes accommodate more discharge product $\mathrm{Li}_{2} \mathrm{O}_{2}$ and show higher specific capacity, which is in agreement with previous reports. For comparison, the typical capacities of nanostructured carbon materials for oxygen electrodes are summarized in Table 2. The specific capacity of CF -50 in this work is higher than those of reported mesoporous carbon materials, and even approaches the reported capacities of graphene-based oxygen electrodes $[11,14,18,19,21-23,27,32]$. The high capacities of CF-Xs benefit from not only the high surface area and pore volume but also the specific 3D architecture of tortuous hollow carbon nanosheets that will be discussed later.

Although $\mathrm{CF}-\mathrm{X}$ electrodes do not have the highest capacities, their polarizations under the voltage cutoff protocol are relatively small compared with the reported carbonaceous oxygen electrodes. High-capacity carbonbased oxygen electrodes usually cannot be fully charged after the full discharge to around $2.0 \mathrm{~V}$ because the high charge overpotential (up to more than $4.5 \mathrm{~V}$ ) of the electrochemical oxidation of $\mathrm{Li}_{2} \mathrm{O}_{2}$ produces lithium ion and oxygen. In the present study, we use the term "reversibility" to express the kinetic features of the oxygen electrodes. Good reversibility means that the charge/ discharge polarization of $\mathrm{Li}-\mathrm{O}_{2}$ cells is small and the $\mathrm{Li}-$ $\mathrm{O}_{2}$ cells could be fully discharged/charged in the voltage ranges from 2.2 to $4.5 \mathrm{~V}$. Generally, the reversibility of carbon-based oxygen electrodes is very poor. As shown in Fig. 5a, SP electrode cannot be charged with a charge cutoff voltage of $4.5 \mathrm{~V}$ at the current densities from 100 to $300 \mathrm{~mA} \mathrm{~h} \mathrm{~g}^{-1}$ after the discharge to $2.2 \mathrm{~V}$. When discharged to around $2.0 \mathrm{~V}$, large particles or thick films of $\mathrm{Li}_{2} \mathrm{O}_{2}$ will grow inside the oxygen electrode to terminate the discharge process $[5,33]$. Since the surface area and pore volume of SP are small, poor electric contacts between the SP powders and the large $\mathrm{Li}_{2} \mathrm{O}_{2}$ particles result in very high charge overpotential. Consequently, the reversibility of SP electrode is expected to be very poor. In contrast, the reversibility of $\mathrm{CF}-\mathrm{Xs}$ electrodes in the present work is much better than that of 
Table 2 Full-discharge properties of previously reported $\mathrm{Li}^{-} \mathrm{O}_{2}$ batteries with nanostructured carbon-based oxygen cathodes compared to this work

\begin{tabular}{|c|c|c|c|c|c|c|c|c|}
\hline \multirow[b]{2}{*}{ Materials } & \multirow{2}{*}{$\begin{array}{l}\text { Electrode } \\
\text { preparation }\end{array}$} & \multirow{2}{*}{$\begin{array}{l}\text { Mass loading } \\
\left(\mathrm{mg} \mathrm{cm}^{-2}\right)\end{array}$} & \multirow[b]{2}{*}{ Electrolyte } & \multicolumn{2}{|c|}{ Current density } & \multicolumn{2}{|c|}{ Discharge capacity } & \multirow{2}{*}{$\begin{array}{l}\text { Publication } \\
\text { year [Ref] }\end{array}$} \\
\hline & & & & $\begin{array}{c}\text { Gravimetric } \\
\left(\mathrm{mA} \mathrm{g}^{-1}\right)\end{array}$ & $\begin{array}{c}\text { Areal } \\
\left(\mathrm{mA} \mathrm{cm}^{-2}\right)\end{array}$ & $\begin{array}{c}\text { Gravimetric } \\
\left(\mathrm{mA} \mathrm{h} \mathrm{g}^{-1}\right)\end{array}$ & $\begin{array}{c}\text { Areal } \\
\left(\mathrm{mA} \mathrm{h} \mathrm{cm}^{-2}\right)\end{array}$ & \\
\hline $\begin{array}{l}\text { Ball-flower-like carbon } \\
\text { microspheres }(\mathrm{CF}-50)\end{array}$ & Slurry & 1 & $\begin{array}{l}1 \mathrm{~mol} \mathrm{~L}^{-1} \\
\text { LiTFSI in } \\
\text { TEGDME }\end{array}$ & 100 & 0.1 & 9163.7 & 9.16 & This work \\
\hline $\begin{array}{l}\text { Mesocellular } \\
\text { carbon foam }\end{array}$ & $\begin{array}{c}\text { Dry } \\
\text { Compression }\end{array}$ & 1 & $\begin{array}{c}1 \mathrm{~mol} \mathrm{~L}^{-1} \\
\mathrm{LiClO}_{4} \text { in PC }\end{array}$ & I & 0.1 & 2500 & l & $2009[18]$ \\
\hline Graphene & Dry rolling & 2.1 & $\begin{array}{l}1 \mathrm{~mol} \mathrm{~L}^{-1} \\
\text { LiTFSI in Tri- } \\
\text { glyme }\end{array}$ & $\underline{47.6}$ & 0.1 & 15000 & $\underline{31.5}$ & $2011[21]$ \\
\hline $\begin{array}{l}\text { 3D porous } \\
\text { graphene framework }\end{array}$ & Free standing & $\underline{0.71}$ & $\begin{array}{c}1 \mathrm{~mol} \mathrm{~L}^{-1} \\
\text { LiTFSI in DME }\end{array}$ & 280 & 0.2 & 11060 & $\underline{7.85}$ & 2012 [22] \\
\hline $\begin{array}{l}\text { Ketjen black EC600JD } \\
\text { and super P (weight } \\
\text { ratio of } 5: 1 \text { ) }\end{array}$ & Laminated & $6.7 \pm 0.4$ & $\begin{array}{c}1 \mathrm{~mol} \mathrm{~L}^{-1} \\
\mathrm{LiClO}_{4} \text { in PC }\end{array}$ & 30 & $\underline{0.2}$ & 1219 & $\underline{8.2}$ & 2013 [32] \\
\hline $\begin{array}{l}\text { Nitrogen enriched } \\
\text { mesoporous carbon }\end{array}$ & $\begin{array}{c}\text { Dry } \\
\text { Compression }\end{array}$ & $\underline{3.39}$ & $\begin{array}{l}1 \mathrm{~mol} \mathrm{~L}^{-1} \\
\text { LiTFSI in } \\
\text { TEGDME }\end{array}$ & 30 & $\underline{0.1}$ & 4500 & $\underline{15.3}$ & 2013 [19] \\
\hline $\begin{array}{l}\text { Hierarchical meso/ } \\
\text { macro structure porous } \\
\text { carbon black }\end{array}$ & Slurry & $\underline{1.5}$ & $\begin{array}{c}1 \mathrm{~mol} \mathrm{~L}^{-1} \\
\mathrm{LiClO}_{4} \text { in EC/PC } \\
(1: 1)\end{array}$ & $\underline{67}$ & $\underline{0.1}$ & 3600 & $\underline{5.4}$ & $2014[20]$ \\
\hline $\begin{array}{l}\text { Mesoporous } \\
\text { carbon nanocube }\end{array}$ & Slurry & 0.5 & $\begin{array}{c}0.1 \mathrm{~mol} \mathrm{~L}^{-1} \\
\mathrm{LiClO}_{4} \text { in DMSO }\end{array}$ & 200 & $\underline{0.1}$ & 22390 & $\underline{11.2}$ & 2015 [27] \\
\hline $\begin{array}{l}\text { Three dimensionally } \\
\text { ordered mesoporous } \\
\text { carbon }\end{array}$ & Slurry & $0.5-1$ & $\begin{array}{l}1.0 \mathrm{~mol} \mathrm{~L}^{-1} \\
\mathrm{LiClO}_{4} \text { in } \\
\mathrm{TEGDME}^{2}\end{array}$ & 200 & $\underline{0.1}$ & 6300 & $\underline{3.15}$ & 2015 [35] \\
\hline $\begin{array}{l}\text { Hierarchical } \\
\text { macroporous } \\
\text { active carbon } \\
\text { fiber }\end{array}$ & $\begin{array}{l}\text { Free- } \\
\text { standing }\end{array}$ & l & $\begin{array}{c}0.05 \mathrm{~mol} \mathrm{~L}^{-1} \mathrm{LiI} \\
\text { and } 1 \mathrm{~mol} \mathrm{~L}^{-1} \\
\mathrm{LiCF}_{3} \mathrm{SO}_{3} \text { in } \\
\mathrm{TEGDME}^{-}\end{array}$ & 1000 & l & 13290 & I & $2016[11]$ \\
\hline Holey graphene & $\begin{array}{c}\text { Dry } \\
\text { Compression }\end{array}$ & 5 & $\begin{array}{l}1 \text { mol L }{ }^{-1} \text { LiTFSI } \\
\text { in TEGDME }\end{array}$ & 20 & 0.1 & 7667 & 37.3 & 2017 [23] \\
\hline
\end{tabular}

"Underlined numbers were calculated or estimated based on available data in the respective reports. Data not available in the references are presented as lines in the table.

the SP electrode. Fig. 5b clearly show that $\mathrm{CF}-100$ electrode is rechargeable at all the current densities from 2.2 to $4.5 \mathrm{~V}$. As shown in Fig. $5 \mathrm{c}$ and d, CF- 80 and $\mathrm{CF}-50$ can be charged at 100 and $200 \mathrm{~mA} \mathrm{~g}^{-1}$ with cutoff voltage at $4.5 \mathrm{~V}$ but cannot be charged at $300 \mathrm{~mA} \mathrm{~g}^{-1}$. The Coulombic efficiencies of $\mathrm{CF}-100, \mathrm{CF}-80$, and $\mathrm{CF}-50$ in the first cycle at $100 \mathrm{~mA} \mathrm{~g}^{-1}$ from 2.2 to $4.5 \mathrm{~V}$ are $82.4 \%$, $82.3 \%$, and $91.8 \%$, respectively. So far, few studies report the charge behavior of carbon-based oxygen electrodes after the full discharge to around $2.0 \mathrm{~V}$. For instance, an initial Coulombic efficiency of $61.6 \%$ for the mesoporous carbon nanocubes could be estimated according to the reported voltage profiles in the first cycles according to Sun et al. [27]. Only Xie et al. [14] reported an initial Coulombic efficiency close to $100 \%$ (can be fully charged) and low overpotential for three dimensionally ordered mesoporous carbon. The reversibility of $\mathrm{CF}-\mathrm{Xs}$ electrodes in the present work is much better than those of most reported carbon-based oxygen electrodes.

The highest reversibility and high capacities of $\mathrm{CF}-\mathrm{Xs}$ benefit from both their chemical components and micronano structures. Firstly, the high degree of defect derived from nitrogen doping provides sufficient active sites for OER and ORR [34]. Secondly, the ball-flower-like morphology with high surface area and inner spacing could support more discharge product with well electric contact. Finally, the assembly of tortuous hollow carbon nanosheets forming a 3D architecture unblocks the pathways for ions and gas diffusion inside the oxygen electrode. To further study the structural advantages of $\mathrm{CF}-\mathrm{Xs}$, the discharged cathodes were investigated by Raman spectrum and SEM.

Fig. 6a shows the Raman spectrum of $\mathrm{CF}-50$ electrode discharged to a capacity of $1,000 \mathrm{~mA} \mathrm{~h} \mathrm{~g}^{-1}$. The strong D and $\mathrm{G}$ bands are ascribed to $\mathrm{CF}-50$ and carbon paper. The broadened Raman band centered at $836 \mathrm{~cm}^{-1}$ is 

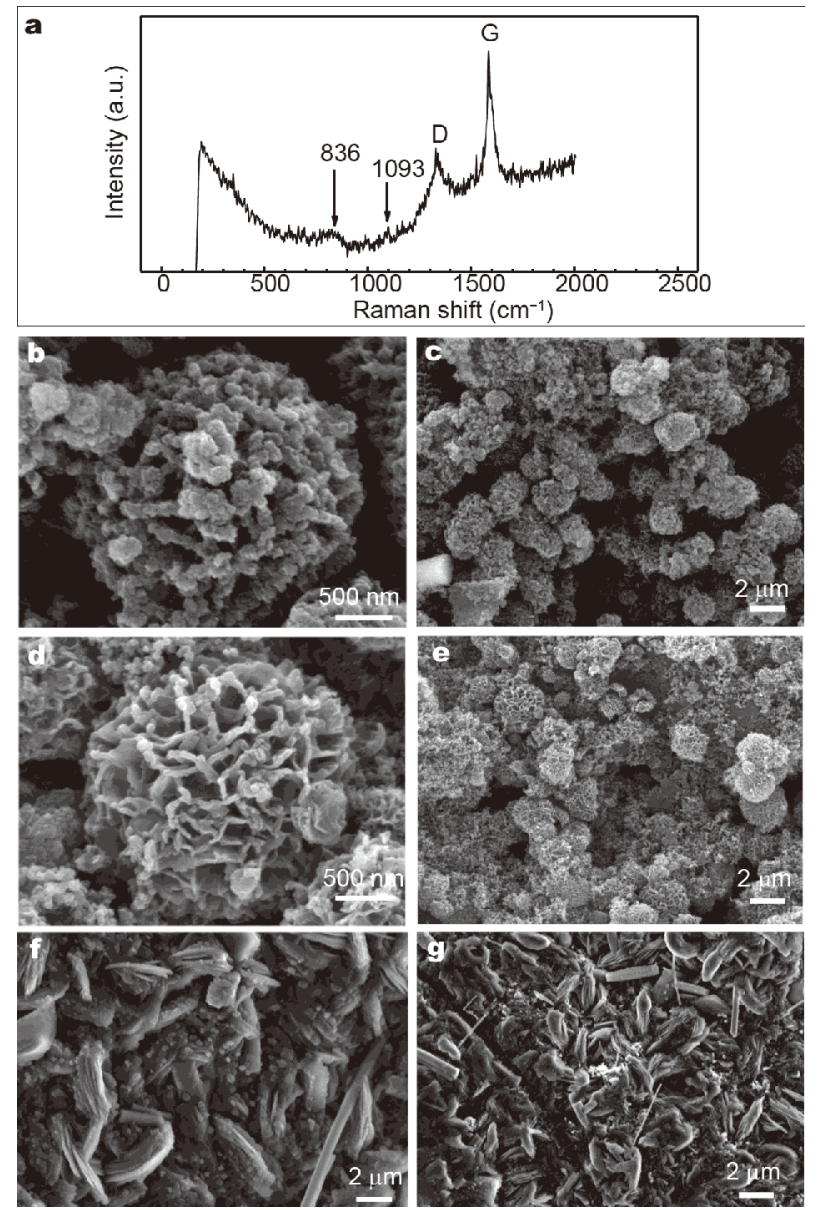

Figure 6 (a) Raman spectrum and (b, c) SEM images of discharged CF -50 electrode with a curtailed capacity of $1,000 \mathrm{~mA} \mathrm{~h} \mathrm{~g}^{-1}$; (d, e) SEM images of charged CF-50 electrode; (f, g) SEM images of CF-50 electrode discharged to $2.2 \mathrm{~V}$.

assigned to the stretching vibration of $\mathrm{LiO}-\mathrm{OLi}$, confirming the $\mathrm{Li}_{2} \mathrm{O}_{2}$ deposition on the cathode [6]. The Raman band at $1,093 \mathrm{~cm}^{-1}$ is associated with the side reaction product $\mathrm{Li}_{2} \mathrm{CO}_{3}$, indicating the corrosion of the carbon cathode under oxygen reduction [6]. Fig. $6 \mathrm{~b}$ and $\mathrm{c}$ are the SEM images of the discharged $\mathrm{CF}-50$ cathode with a curtailed discharge capacity of $1,000 \mathrm{~mA} \mathrm{~h} \mathrm{~g}^{-1}$. It can be seen that $\mathrm{Li}_{2} \mathrm{O}_{2}$ deposit evenly on the surface of the tortuous hollow carbon nanosheets. Namely, the interstice between nanosheets accommodates the discharge product during the initial discharge. The ball-flower-like morphology not only enables the full utilization of the active surface of the carbon microspheres, but also provides inner spacing for discharge product. Then, the discharged CF- 50 cathode was charged to a capacity of $1,000 \mathrm{~mA} \mathrm{~h} \mathrm{~g}^{-1}$ and the charged electrode was investigated by SEM. As shown in Fig. 6d and e, almost all the

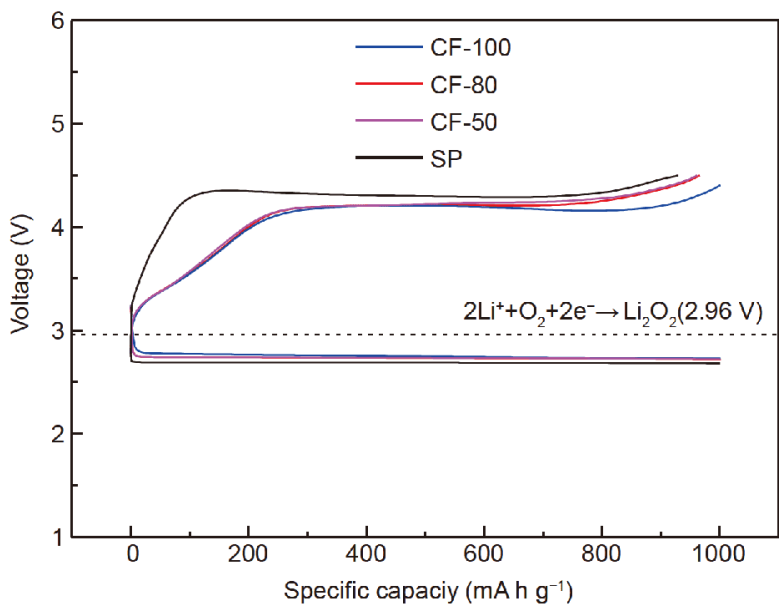

Figure 7 Voltage profiles of SP and CF-Xs with a curtailed specific capacity of $1,000 \mathrm{~mA} \mathrm{~h} \mathrm{~g}^{-1}$ at the current density of $100 \mathrm{~mA} \mathrm{~g}^{-1}$. The thermodynamic equilibrium potential $(2.96 \mathrm{~V})$ of oxygen electrode in the aprotic electrolyte is denoted with the dashed line, when the discharge product is $\mathrm{Li}_{2} \mathrm{O}_{2}$.

deposited $\mathrm{Li}_{2} \mathrm{O}_{2}$ particles on the $\mathrm{CF}-50$ cathode disappear, demonstrating the $\mathrm{CF}-50$ efficiently catalysis for the oxidation of $\mathrm{Li}_{2} \mathrm{O}_{2}$ to release oxygen and lithium ion during the anodic process. When the cathode is discharged to $2.2 \mathrm{~V}$, as shown in Fig. $6 \mathrm{f}$ and $\mathrm{g}$, the microspheres fully covered by toroid-like $\mathrm{Li}_{2} \mathrm{O}_{2}$ particles enable the high discharge capacity. Herein, the ballflower-like structures buried under the $\mathrm{Li}_{2} \mathrm{O}_{2}$ particles would function as electron and gas diffusion in the $3 \mathrm{D}$ network. Therefore, $\mathrm{CF}-\mathrm{X}$ electrodes can be fully charged with a high Coulombic efficiency and exhibit high specific capacities.

$\mathrm{CF}-50$ has the highest capacity among the prepared $\mathrm{CF}-\mathrm{Xs}$, but not the best reversibility. As discussed above, CF-100 could be fully discharged at the current densities from 100 to $300 \mathrm{~mA} \mathrm{~g}^{-1}$. However, $\mathrm{CF}-80$ and $\mathrm{CF}-50$ cannot be charged at $300 \mathrm{~mA} \mathrm{~g}^{-1}$. To further understand this reversibility difference, the voltage profiles of oxygen electrodes utilizing SP and $\mathrm{CF}-\mathrm{Xs}$ with a curtailed specific capacity of $1,000 \mathrm{~mA} \mathrm{~h} \mathrm{~g}^{-1}$ are shown in Fig. 7 . The CF-Xs have lower overpotential in both charge and discharge than SP. Among all three $\mathrm{CF}-\mathrm{Xs}$ samples, CF-100 shows the lowest overpotentials. As compared with Fig. 2, CF-100 has the thickest hollow layers inside the carbon nanosheets, where a 3D architecture will maintain the pathways for ions and gas diffusion inside the oxygen electrode for high reversibility and low polarization. In contrast, the thinner hollow layers of $\mathrm{CF}-50$ and $\mathrm{CF}-80$ might be partially blocked and consequently result in the loss of reversibility at high 

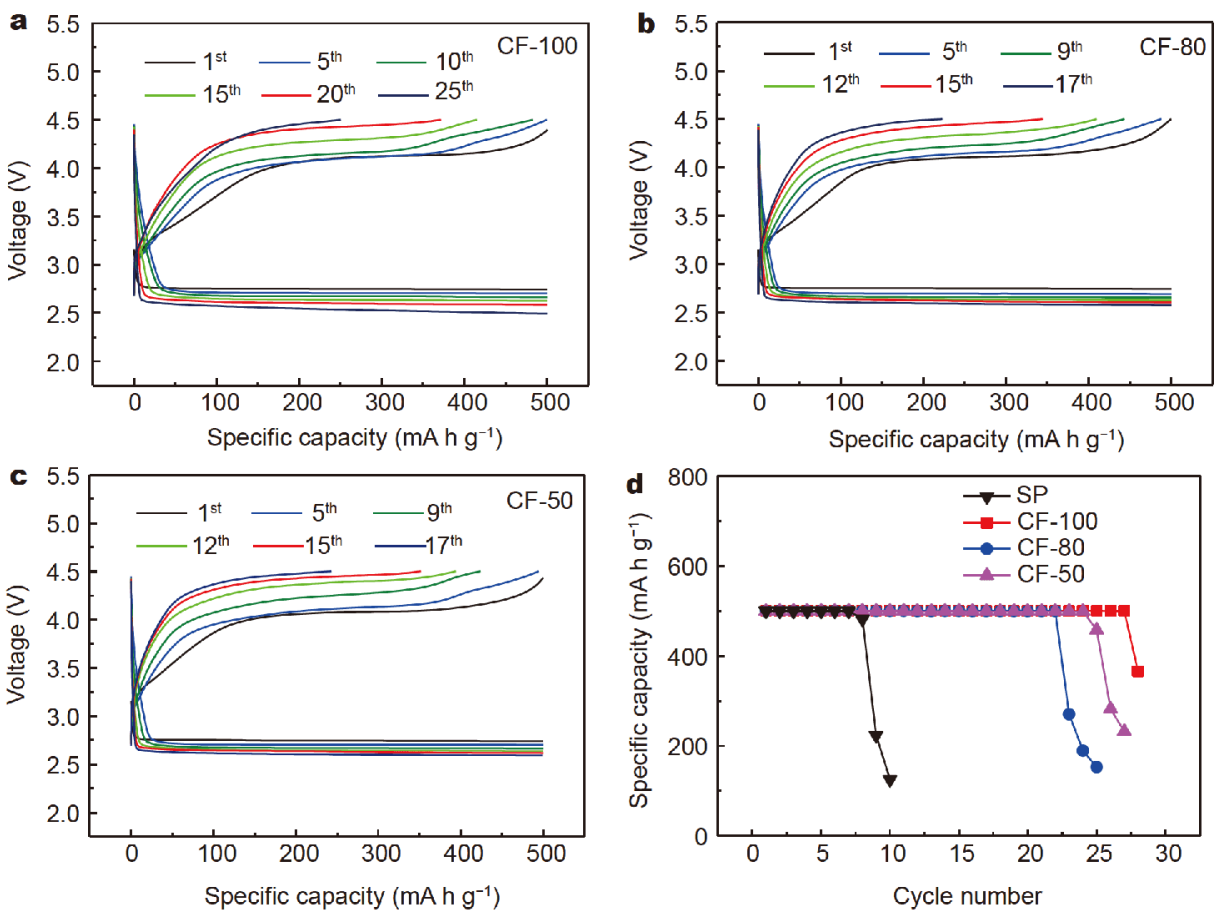

Figure 8 Voltage profiles of $\mathrm{CF}-\mathrm{Xs}$ during cycling at $100 \mathrm{~mA} \mathrm{~g}^{-1}$ with a curtailed specific capacity of $500 \mathrm{~mA} \mathrm{~h} \mathrm{~g}^{-1}:$ (a) $\mathrm{CF}-100$, (b) CF-80 and (c) $\mathrm{CF}-50$; (d) the cycle number comparison of $\mathrm{SP}$ and $\mathrm{CF}-\mathrm{Xs}$.

current densities. In Fig. 8, due to its structure, $\mathrm{CF}-100$ exhibits the best cycling performance among all the CF -Xs. Actually, the cycling performance of $\mathrm{CF}-\mathrm{Xs}$ is still poor due to the accumulated side reaction product on the carbon surface at high voltage up to $4.5 \mathrm{~V}$. CF- 100 gives a specific capacity of $500 \mathrm{~mA} \mathrm{hg}^{-1}$ for only 28 cycles. Therefore, efficient ORR and OER catalysts loaded on CF -Xs are required to further improve the performance of the oxygen electrodes.

\section{CONCLUSIONS}

Ball-flower-like carbon microspheres assembled with tortuous hollow carbon nanosheets are successfully prepared by a novel 3D replication strategy using zinc oxide microspheres as the template and the polydopamine layer as the carbon precursor. When used as oxygen electrodes for $\mathrm{Li}-\mathrm{O}_{2}$ batteries, all the prepared carbon microspheres exhibit both high specific capacities and excellent reversibility. $\mathrm{CF}-50$ with the smallest hollow layers shows the high specific capacity of $9,163.7 \mathrm{~mA} \mathrm{~h} \mathrm{~g}^{-1}$ at a current density of $100 \mathrm{~mA} \mathrm{~g}^{-1}$. The high capacities and excellent reversibility of ballflower-like carbon microspheres are ascribed to the specially designed 3D porous architecture and more defects derived from nitrogen doping. The porous 3D architecture can accommodate the discharge product $\mathrm{Li}_{2} \mathrm{O}_{2}$ and simultaneously maintain the ions and gas diffusion paths. Moreover, more defects provide sufficient active sites for ORR and OER. Our work provides a unique strategy to design 3D porous carbon electrode for high-performance $\mathrm{Li}-\mathrm{O}_{2}$ batteries.

Received 14 August 2018; accepted 16 October 2018; published online 9 November 2018

1 Lu J, Li L, Park JB, et al. Aprotic and aqueous $\mathrm{Li}-\mathrm{O}_{2}$ batteries. Chem Rev, 2014, 114: 5611-5640

2 Wang L, Zhang Y, Liu Z, et al. Understanding oxygen electrochemistry in aprotic $\mathrm{Li}-\mathrm{O}_{2}$ batteries. Green Energy Environ, 2017, 2: 186-203

3 Feng N, He P, Zhou H. Critical challenges in rechargeable aprotic Li- $\mathrm{O}_{2}$ batteries. Adv Energy Mater, 2016, 6: 1502303

4 Aurbach D, McCloskey BD, Nazar LF, et al. Advances in understanding mechanisms underpinning lithium-air batteries. Nat Energy, 2016, 1: 16128

5 Adams BD, Radtke C, Black R, et al. Current density dependence of peroxide formation in the $\mathrm{Li}-\mathrm{O}_{2}$ battery and its effect on charge. Energy Environ Sci, 2013, 6: 1772-1778

6 Peng Z, Freunberger SA, Chen Y, et al. A reversible and higherrate $\mathrm{Li}-\mathrm{O}_{2}$ battery. Science, 2012, 337: 563-566

7 Viswanathan V, Thygesen KS, Hummelshøj JS, et al. Electrical conductivity in $\mathrm{Li}_{2} \mathrm{O}_{2}$ and its role in determining capacity limitations in non-aqueous $\mathrm{Li}^{-} \mathrm{O}_{2}$ batteries. J Chem Phys, 2011, 
135: 214704

8 Liu Y, He P, Zhou H. Rechargeable solid-state Li-air and Li-S batteries: Materials, construction, and challenges. Adv Energy Mater, 2018, 8: 1701602

9 Song K, Agyeman DA, Jung J, et al. A review of the design strategies for tailored cathode catalyst materials in rechargeable Li$\mathrm{O}_{2}$ batteries. Isr J Chem, 2015, 55: 458-471

10 Ma Z, Yuan X, Li L, et al. A review of cathode materials and structures for rechargeable lithium-air batteries. Energy Environ Sci, 2015, 8: 2144-2198

11 Yin YB, Xu JJ, Liu QC, et al. Macroporous interconnected hollow carbon nanofibers inspired by golden-toad eggs toward a binderfree, high-rate, and flexible electrode. Adv Mater, 2016, 28: 74947500

12 Guo Z, Zhou D, Dong XL, et al. Ordered hierarchical mesoporous/ macroporous carbon: a high-performance catalyst for rechargeable Li- $\mathrm{O}_{2}$ batteries. Adv Mater, 2013, 25: 5668-5672

13 Shu C, Li B, Zhang B, et al. Hierarchical nitrogen-doped graphene/ carbon nanotube composite cathode for lithium-oxygen batteries. ChemSusChem, 2015, 8: 3973-3976

14 Sun B, Huang X, Chen S, et al. Porous graphene nanoarchitectures: an efficient catalyst for low charge-overpotential, long life, and high capacity lithium-oxygen batteries. Nano Lett, 2014, 14: 31453152

15 Lu J, Lei Y, Lau KC, et al. A nanostructured cathode architecture for low charge overpotential in lithium-oxygen batteries. Nat Commun, 2013, 4: 2383

16 Franco AA, Xue KH. Carbon-based electrodes for lithium air batteries: Scientific and technological challenges from a modeling perspective. ECS J Solid State Sci Technol, 2013, 2: M3084-M3100

17 Tran C, Yang XQ, Qu D. Investigation of the gas-diffusionelectrode used as lithium/air cathode in non-aqueous electrolyte and the importance of carbon material porosity. J Power Sources, 2010, 195: 2057-2063

18 Yang X, He P, Xia Y. Preparation of mesocellular carbon foam and its application for lithium/oxygen battery. Electrochem Commun, 2009, 11: 1127-1130

19 Nie H, Zhang H, Zhang Y, et al. Nitrogen enriched mesoporous carbon as a high capacity cathode in lithium-oxygen batteries. Nanoscale, 2013, 5: 8484-8487

20 Kang J, Li OL, Saito N. Hierarchical meso-macro structure porous carbon black as electrode materials in Li-air battery. J Power Sources, 2014, 261: 156-161

21 Xiao J, Mei D, Li X, et al. Hierarchically porous graphene as a lithium-air battery electrode. Nano Lett, 2011, 11: 5071-5078

22 Wang ZL, Xu D, Xu JJ, et al. Graphene oxide gel-derived, freestanding, hierarchically porous carbon for high-capacity and highrate rechargeable $\mathrm{Li}_{-} \mathrm{O}_{2}$ batteries. Adv Funct Mater, 2012, 22: 36993705

23 Lin Y, Moitoso B, Martinez-Martinez C, et al. Ultrahigh-capacity lithium-oxygen batteries enabled by dry-pressed holey graphene air cathodes. Nano Lett, 2017, 17: 3252-3260

24 McCloskey BD, Speidel A, Scheffler R, et al. Twin problems of interfacial carbonate formation in nonaqueous $\mathrm{Li}-\mathrm{O}_{2}$ batteries. J Phys Chem Lett, 2012, 3: 997-1001

25 Ottakam Thotiyl MM, Freunberger SA, Peng Z, et al. The carbon electrode in nonaqueous $\mathrm{Li}-\mathrm{O}_{2}$ cells. J Am Chem Soc, 2013, 135: 494-500

26 Yao X, Dong Q, Cheng Q, et al. Why do lithium-oxygen batteries fail: Parasitic chemical reactions and their synergistic effect. Angew Chem Int Ed, 2016, 55: 11344-11353

27 Sun B, Chen S, Liu H, et al. Mesoporous carbon nanocube architecture for high-performance lithium-oxygen batteries. Adv Funct Mater, 2015, 25: 4436-4444

28 Liu Y, Ai K, Lu L. Polydopamine and its derivative materials: Synthesis and promising applications in energy, environmental, and biomedical fields. Chem Rev, 2014, 114: 5057-5115

29 Xiao L, Mei D, Cao M, et al. Effects of structural patterns and degree of crystallinity on the performance of nanostructured $\mathrm{ZnO}$ as anode material for lithium-ion batteries. J Alloys Compd, 2015, 627: 455-462

30 Kuo CL, Kuo TJ, Huang MH. Hydrothermal synthesis of $\mathrm{ZnO}$ microspheres and hexagonal microrods with sheetlike and platelike nanostructures. J Phys Chem B, 2005, 109: 20115-20121

31 Kaneko K. Determination of pore size and pore size distribution. J Membrane Sci, 1994, 96: 59-89

32 Zhang Y, Zhang H, Li J, et al. The use of mixed carbon materials with improved oxygen transport in a lithium-air battery. J Power Sources, 2013, 240: 390-396

33 Horstmann B, Gallant B, Mitchell R, et al. Rate-dependent morphology of $\mathrm{Li}_{2} \mathrm{O}_{2}$ growth in $\mathrm{Li}-\mathrm{O}_{2}$ batteries. J Phys Chem Lett, 2013, 4: 4217-4222

34 Kichambare P, Kumar J, Rodrigues S, et al. Electrochemical performance of highly mesoporous nitrogen doped carbon cathode in lithium-oxygen batteries. J Power Sources, 2011, 196: 33103316

35 Xie J, Yao X, Cheng Q, et al. Three dimensionally ordered mesoporous carbon as a stable, high-performance $\mathrm{Li}-\mathrm{O}_{2}$ battery cathode. Angew Chem Int Ed, 2015, 54: 4299-4303

Acknowledgements This work was supported by grants from the National Natural Science Foundation of China (21673169 and 51672205), the National Key R\&D Program of China (2016YFA0202602), the Research Start-Up Fund from Wuhan University of Technology, and the Fundamental Research Funds for the Central Universities (WUT: 2017IB005, 2016IVA083).

Author contributions Xiao L, Yi J, Meng W and Wang S performed the experiments; Xiao L and Liu J wrote the paper. All authors contributed to the general discussion.

Conflict of interest The authors declare no conflict of interest.

Supplementary information Supplementary data are available in the online version of the paper. 

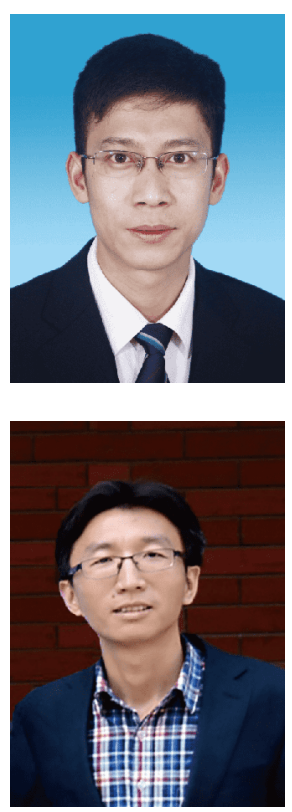

Liang Xiao received his $\mathrm{PhD}$ degree in physical chemistry from Wuhan University. He worked at Pacific Northwest National Laboratory as a visiting scholar for one year from 2013 to 2014. He is currently a Professor at the School of Chemistry, Chemical Engineering and Life Sciences, Wuhan University of Technology. His current research focuses on nanostructured materials for lithium ion batteries and metal air batteries.
Jinping Liu received his PhD degree from Central China Normal University in June 2009. During 2008-2011, he did visiting and post-doctoral research at Nanyang Technological University in Singapore. He is currently Chair Professor at Wuhan University of Technology. His research interest includes the synthesis and electrochemical applications (batteries, supercapacitors \& electrocatalysis) of nanostructures.

\section{锂氧电池高容量正极材料花球状碳微球的三维复刻构筑}

肖亮 ${ }^{1^{*}}$, 易靖宇 ${ }^{1}$, 孟文 ${ }^{1}$, 王诗瑶 ${ }^{1}$, 邓伯华 ${ }^{1}$, 刘金平 ${ }^{1,2^{*}}$

摘要 活性物质和电极的多孔结构设计是实现锂氧电池中氧气电极高容量和良好可逆性的关键措施. 本文报道了一种创新的三维复刻策 略, 并用于设计锂氧电池氧气电极用多孔碳材料的三维结构. 作为一个实例, 采用聚多巴胺包覆层为碳源, 通过完整复制纳米结构氧化锌 模板的形貌, 成功地制备了由扭曲的中空碳纳米片组装而成的花球状碳微球. 作为氧气电极的活性物质, 花球状碳微球的三维多孔结构不 仅能容纳放电产物过氧化锂, 同时也能保持离子和气体的扩散通道. 此外, 氮掺杂引入的高缺陷为氧还原/析出反应提供了充足的活性位 点. 从而, 花球状碳微球表现出高达 $9163.7 \mathrm{~mA} \mathrm{~h} \mathrm{~g}$ 的比容量和优异的可逆性. 本工作呈现了一种用于能源存储和转化的多孔碳材料的三 维结构的有效可控制备方法, 即复制过渡金属氧化物模板的纳米结构. 